\title{
Proven prevention tools for addressing STI epidemics
}

\author{
Anatole S. Menon-Johansson(i)
}

\begin{abstract}
The ongoing rise of sexually transmitted infections (STIs) poses a global public health challenge and the risk of acquiring one of these infections depends upon sexual practices, the number of sexual encounters and the location of that individual within the sexual network. Commercial sex workers (CSWs) have potentially a pivotal role in the transmission of STIs; however, a new study presented in this journal describes markers of risk but no increase in infections amongst men who pay for sex (MPS). This commentary highlights some of the growing evidence regarding STI prevention and the value of using these tools to protect CSWs, their clients and by extension the sexual partners of MPS.
\end{abstract}

The transmission of Sexually Transmitted Infections (STIs) depends upon the number of sexual partners, the number of concurrent partners and the coital frequency [1]. A recent special edition of the Lancet highlighted the importance of STIs, with an estimated 11 transmissions per second, and the challenges of STI control globally [2]. STI transmission between individuals depends upon their position in the sexual network: Commercial Sex Workers (CSWs) have the potential to spread infections to multiple Men who Pay for Sex (MPS) who in turn can further spread or 'bridge' these infections to subsequent sexual partners in lower risk sexual networks [3]. Since the majority of STI infections do not lead to noticeable symptoms, the unwitting transmission of infections to and from MPS has the potential to drive epidemics and studies have shown a higher rate of STIs in MPS $[4,5]$.

The paper by Rich et at in this journal [6] has looked at the number of men attending open access sexual health services in Israel over 7 years and found that $27 \%$ were MPS. This group of men reported more at-risk behaviours such as increased partner number, drug taking and a history of STI diagnoses than the men that did not pay for sex; however, in this analysis no additional STI diagnoses were made in MPS.

Correspondence: anatole.menon-johansson@gstt.nhs.uk

Burrell Street Sexual Health Clinic, Guy's \& St Thomas' NHS Foundation Trust, 4-5 Burrell Street, London SE1 OUN, UK
Across the World commercial sex work provides convenient sexual intimacy and Israel, like many nations, is grappling with the best way to legislate an industry that is associated with exploitation [7]. The CSWs can play an important public health role and the effective implementation of prevention strategies in this group has the potential to reduce the transmission of infections. Table 1 highlights a range of proven tools that reduce STI transmission during penetrative sex and CSWs should be supported to access and use all of them in their work.

Prevention of Human Papilloma, Hepatitis A \& B Viruses with vaccination and Human Immunodeficiency Virus (HIV) with Pre-exposure prophylaxis ensures that the risk of acquisition and then onward transmission from a CSW would be negligible. Similarly, if the CSW is already HIV positive, then treatment as prevention would stop onward transmission of the virus to MPS. The role of condoms to prevent bacterial and parasitic infections is still key as a public health intervention and CSWs need to be supported to use them for vaginal, anal and oral sex.

The biggest burden of poor sexual health in the future will come from non-viral infections and drug resistance is a growing challenge within these organisms [2]. Regular STI testing of 'at risk' individuals is important to identify infections within a sexual network and this needs to be complemented with effective partner notification to limit onward spread of these infections.

(c) The Author(s). 2018 Open Access This article is distributed under the terms of the Creative Commons Attribution 4.0 International License (http://creativecommons.org/licenses/by/4.0/), which permits unrestricted use, distribution, and 
Table 1 Shows the prevention strategies that have been developed to protect against sexually transmitted infections and their effectiveness

\begin{tabular}{|c|c|c|}
\hline $\begin{array}{l}\text { Sexually Transmitted } \\
\text { Infection }\end{array}$ & $\begin{array}{l}\text { Prevention } \\
\text { strategies* }\end{array}$ & Effectiveness \\
\hline \multirow{3}{*}{$\begin{array}{l}\text { Non-viral infections } \\
\text { (Chlamydia trachomatis/ } \\
\text { Neisseria gonorrhoea/ } \\
\text { Trichomonas vaginalis/ } \\
\text { Mycoplasma genitalium/ } \\
\text { Ureaplasma urealyticum/ } \\
\text { Treponema pallidum) }\end{array}$} & -Condoms & $\begin{array}{l}.90 \% \text { effective with } \\
\text { perfect use [10] }\end{array}$ \\
\hline & $\begin{array}{l}\text {-Testing for STIs } \\
\text { and treating } \\
\text { when necessary }\end{array}$ & $\begin{array}{l}\text {-100\% effective unless } \\
\text { there is poor adherence } \\
\text { to treatment, reinfection } \\
\text { or drug resistance }\end{array}$ \\
\hline & $\begin{array}{l}\text { - Partner } \\
\text { notification }\end{array}$ & $\begin{array}{l}\text { - Reducing onward } \\
\text { transmission, reinfection } \\
\text { and the cost to make an } \\
\text { STI diagnosis [11] }\end{array}$ \\
\hline \multirow{3}{*}{$\begin{array}{l}\text { Human papilloma virus } \\
\text { (HPV) }\end{array}$} & ·Condoms & -Up to $50 \%[12]$ \\
\hline & -Circumcision & •50\% [13] \\
\hline & $\begin{array}{l}\cdot H P V \\
\text { vaccination }\end{array}$ & $.90 \%[14]$ \\
\hline \multirow[t]{2}{*}{ Hepatitis A virus (HAV) } & -Condoms & -Not known \\
\hline & $\begin{array}{l}\cdot \text { Hepatitis A } \\
\text { vaccination }\end{array}$ & $.93 \%$ [15] \\
\hline \multirow[t]{2}{*}{ Hepatitis B virus (HBV) } & -Condoms & -Not known \\
\hline & $\begin{array}{l}\cdot \text { Hepatitis B } \\
\text { vaccination }\end{array}$ & $\cdot>90 \%[16]$ \\
\hline \multirow[t]{2}{*}{ Herpes virus (HSV 1 \& 2) } & -Condoms & $\cdot 24 \%[17]$ \\
\hline & $\begin{array}{l}\text {-Prophylactic } \\
\text { treatment }\end{array}$ & •48\% [17] \\
\hline \multirow{4}{*}{$\begin{array}{l}\text { Human Immunodeficiency } \\
\text { Virus (HIV) }\end{array}$} & -Condoms & •10\% [18] \\
\hline & -Circumcision & $\cdot 57 \%[13]$ \\
\hline & $\begin{array}{l}\text {-Treatment as } \\
\text { prevention }\end{array}$ & $.93 \%$ [19] \\
\hline & $\begin{array}{l}\text {-Preexposure } \\
\text { prophylaxis } \\
\text { (PrEP) }\end{array}$ & • > 90\% [20] \\
\hline
\end{tabular}

*Abstinence has not been included since it is a rare component of the CSW client relationship

Finally, a history of sex with CSWs was not shown to be associated with acquisition of an STI in one Israeli clinic over 7 years. It is likely that the use of condoms played a pivotal role in this outcome and the high prevalence of circumcision within the men in this study is likely to have contributed too [8]. It is important to build upon these results and focus on CSW access to the prevention methods cited in the table as well as address prejudice against CSWs and their clients [9].

\section{Conclusions}

There are a number of proven prevention tools for STI epidemics. The challenge is to ensure that patient education, staff training, and health care policy initiatives focus on the full use of prevention tools to improve the publics' health.

\section{Acknowledgements}

I would like to thank the editors of IJHPR for the opportunity to write this commentary.

\section{Authors' contributions}

There was only one author on this paper. The author read and approved the final manuscript.

\section{Ethics approval and consent to participate}

Not relevant.

\section{Consent for publication}

Given by the sole author submitting this work.

\section{Competing interests}

The author declares that he/she has no competing interests.

\section{Publisher's Note}

Springer Nature remains neutral with regard to jurisdictional claims in published maps and institutional affiliations.

Received: 4 July 2018 Accepted: 29 July 2018

Published online: 06 August 2018

\section{References}

1. Nordvik MK, Liljeros F. Number of sexual encounters involving intercourse and the transmission of sexually transmitted infections. Sexually Transm Dis. 2006;33(6):342-9.

2. Unemo M, Bradshaw CS, Hocking JS, de Vries HJC, Francis SC, et al. Sexually transmitted infections: challenges ahead. Lancet Infect Dis. 2017;17:e235-79.

3. Ward H. Prevention strategies for sexually transmitted infections: importance of sexual network structure and epidemic phase. Sex Transm Infect. 2007;83(Suppl I):i43-9.

4. Decker MR, Raj A, Gupta J, Silverman JG. Sex purchasing and associations with HIV/sexually transmitted infections among a clinic-based sample of US men. J Acquir Immune Defic Syndr. 2008;48(3):335-59.

5. McLaughlin MM, Chow EPF, Wang C, Li-Gang Y, Yang B, et al. Sexually transmitted infections among heterosexual male clients of female sex Workers in China: a systematic review and meta-analysis. PLoS One. 2013: 8(8):e71394.

6. Rich R, Leventhal A, Sheffer R, Zohar M. Heterosexual men who purchase sex and attended an STI clinic in Israel characteristics and sexual behavior. Israel J Health Policy Res. 2018;7(1):19. https://doi.org/10.1186/s13584-018-0213-4.

7. Newman M (2016) In anti-prostitution battle, Israel takes a trick out of Europe's book https://www.timesofisrael.com/in-anti-prostitution-battleisrael-may-join-europe-in-punishing-johns/ (Last Accessed 10th June 2018).

8. Chemtob D, Op de Coul E, Van Sighem A, Mor Z, Cazein F, Semaille C. Impact of Male Circumcision among heterosexual HIV cases: comparison between three low HIV prevalence countries. Israel J Health Policy Res. 2015;4:36.

9. Fowler N. Don't die of prejudice: Biteback Publishing Ltd; 2014. ISBN 978-184954-748-2

10. Garnett GP, White PJ, Ward H. Fewer partners or more condoms? Modelling the effectiveness of STI prevention interventions. Sex Transm Infect. 2008; 84(Suppl II):ii4-ii11.

11. Althaus CL, Turner KME, Mercer $\mathrm{CH}$, Auguste P, Roberts TE, Bell G, et al. Effectiveness and cost-effectiveness of traditional and new partner notification technologies for curable sexually transmitted infections: observational study, systematic reviews and mathematical modelling. Health Technol Access. 2014;18(2):1-100.

12. Lam JUH, Rebolj M, Dugué PA, Bonde J, von Euler-Chelpin M, et al. Condom use in prevention of human papillomavirus infections and cervical neoplasia: systematic review of longitudinal studies. J Med Screen. 2014; 21(1):38-50

13. Friedman B, Khoury J, Petersiel N, Yahalomi T, Paul M, Neuberger A. Pros and cons of circumcision: an evidence-based overview. Clin Med Micro and Infection. 2016;22:768-74.

14. Garland SM, Kjaer SK, Muñoz N, Block SL, Brown DR, et al. Impact and effectiveness of the Quadrivalent human papillomavirus vaccine: a systematic review of 10 years of real-world experience. Clin Infect Dis. 2016; 63(4):519-27. 
15. Irving GJ, Holden J, Yang R, Pope D. Hepatitis A immunisation in persons not previously exposed to hepatitis A. Cochrane Database Syst Rev. 2012; (Issue 7):Art No.:CD009051.

16. Francis DP, Hadler SC, Thompson SE, Maynard JE, Orstrow DG, et al. The prevention of hepatitis B with vaccine. Ann Intern Med. 1982;97:362-6.

17. Gupta R, Warren T, Wald A. Genital Herpes. Lancet. 2007;370:2127-37.

18. Moreno R, Nababan HY, Ota E, Wariki WMV, Ezoe S, et al. Structural and community-level interventions for increasing condom use to prevent the transmission of HIV and other sexually transmitted infections. Cochrane Database Syst Rev. 2014;(Issue 7):Art. No.: CD003363.

19. Cohen M, Chen YQ, McCauley M, Gamble T, Hosseinipour MC, et al. Antiviral therapy for the prevention of HIV-1 transmission. N Engl J Med. 2016;375: 830-9.

20. Riddell J, Amico R, Mayer KH. HIV Preexposure prophylaxis. JAMA. 2018;319:1261-8.

Ready to submit your research? Choose BMC and benefit from:

- fast, convenient online submission

- thorough peer review by experienced researchers in your field

- rapid publication on acceptance

- support for research data, including large and complex data types

- gold Open Access which fosters wider collaboration and increased citations

- maximum visibility for your research: over $100 \mathrm{M}$ website views per year

At BMC, research is always in progress.

Learn more biomedcentral.com/submissions 